\title{
DISPUTE MANAGEMENT UNDER MODERN CONSTRUCTION SYSTEMS
}

\author{
ROBERT COULSON* \\ I \\ INTRODUCTION
}

No construction method is perfect. Thus, parties entering into any construction contract may find it very beneficial to devote attention, early in the contracting process, to the express provision of some mechanism for resolving disputes. Out-of-court methods of dispute resolution have become increasingly popular. The choice of nonjudicial mechanisms for the resolution of contract disputes is motivated, at least in part, by the desire to avoid ever-increasing costs and time involved in litigation.

The advent of the new approaches to construction-fast tracking, design-build, and construction management-brings more uncertainty into the construction process, since many specifics are not determined at the time the contracts are signed. These uncertainties inevitably lead to more disagreements, which in turn increase the need for some satisfactory means of resolution. This paper analyzes some methods in which an impartial, nonjudicial party is involved in the dispute settlement process.

It is assumed readers are not familiar with how voluntary, binding arbitration is being used in traditional owner-contractor documents. Thus, first, a brief description of that process is given to serve as a basis of comparison. Second, the new approaches to construction and their impact on traditional roles and responsibilities are discussed. Finally, the implications of these changes on the dispute settlement process, and the different settlement methods available are analyzed.

\section{II}

Traditional Construction arbitration

\section{A. Traditional Construction}

In many standard documents, the architect is designated as the first arbiter of disputes between the parties. ${ }^{1}$ This responsibility springs naturally from the infrastructure of the traditional construction contract. The owner hires the architect, who designs plans for the building. Once the owner approves the plans, bids are solicited based on the architect's designs and specifications. When bids are

\footnotetext{
Copyright $(\mathcal{O} 1983$ by Law and Contemporary Problems

* President, American Arbitration Association.

1. See, e.g., American Institute of Architects, General Conditions of the Contract for Construction, Doc. A201, arts. 2.2.7, 2.2.10 (Aug. 1976) [hereinafter cited as AIA General Conditions], reprinted in BusiNESSMAN'S GUIDE TO CONSTR UCTION 198 (1980).
} 
accepted, contracts written according to the architect's specifications are signed. If the owner and his contractor(s) have disagreements over what is required by the contracts or what is to be provided by the contractor, the architect is the logical party to "interpret" the contract requirements. If settlement does not evolve from the good offices of the architect, or from their own negotiations, the parties must resort to some third party for resolution.

\section{B. Voluntary, Binding Arbitration}

The parties can provide a mechanism for resolving disputes by mutually agreeing to submit future disputes to arbitration. In addition, the parties can refer to the Construction Industry Arbitration Rules of the American Arbitration Association (AAA) to provide an established framework for the arbitration. ${ }^{2}$

In the absence of such an arbitration clause, parties can bring an existing dispute to arbitration by negotiating a submission agreement in which the parties describe the issue between them and agree to arbitrate.

On receiving the Demand for Arbitration or Submission Agreement, the AAA appoints the arbitrator(s). One is appointed for a small claim, three for a larger or more complex case. Lists of potential arbitrators are first submitted to the parties to allow them to designate those who are preferred and those who are unacceptable. No arbitrator deemed unacceptable by either side is appointed; mutual preferences are accommodated. ${ }^{3}$

The AAA handles the administrative functions, making all arrangements for the hearing, to avoid the opportunity for either party to unfairly influence the arbitrators. A prehearing conference may be scheduled when it will be useful to establish or settle some procedural details. ${ }^{4}$

Arbitration hearings are less formal than court trials. Rather than following legal rules of evidence, arbitrators listen to all relevant evidence. ${ }^{5}$ Like factfinders in a court, however, the arbitrators decide what weight to give to any evidence. ${ }^{6}$ Within thirty days, the arbitrator renders the award, which conclusively disposes of the controversy. Unless applicable law provides for reopening, the decision can be changed only if both parties agree to reopen the case. ${ }^{7}$

2. AIA General Conditions, supra note 1, art. 7.9.1. states: "All claims, disputes and other matters in question between Contractor and Owner arising out of, or relating to, the Contract Documents . . . shall be decided by arbitration in accordance with the Construction Industry Arbitration Rules of the American Arbitration Association unless the parties mutually agree otherwise."

It should also be noted that an agreement to arbitrate will also exist if the parties to the contract (most frequently, a subcontract) incorporate therein the standard form or other general conditions which contain an arbitration clause. See J.S. \& H. Constr. Co. v. Richmond County Hosp. Auth., 473 F.2d 212 (5th Cir. 1973).

3. American Arbitration Association, Construction Industry arbitration Rules Rule No. 13 (1982).

4. Id. Rule No. 10.

5. Id. Rule No. 31 .

6. Id. Rule No. 32.

7. Id. Rule No. 36 . 


\section{III}

\section{New Construction Methods}

\section{A. Fast Tracking}

Fast track construction is a performance procedure; the traditional roles of the parties-owner, architect, contractor, subcontractor-remain substantially unchanged. The sequence of work, however, changes substantially. A project concept is formulated, then bids are accepted, and then design and construction progress simultaneously. Created in reaction to high interest rates and inflation of material and labor costs, the aim of this procedure is to complete the project quickly.

Once the project concept is formulated, the owner and the design professional determine the necessary separate bid packages and develop a work schedule. The building design itself is integrated into the schedule of unit completion. Early bids must dovetail with long lead items on the job site. ${ }^{8}$

To use a fast track procedure effectively, the parties must accept certain principles inherent in the process. When developing the working drawings and specifications, it is fundamental that what is done is just as important as when it is done. The urgency of the process has an impact on the dispute settlement attitudes of the participants. Once construction is under way, greater flexibility in performance is required than in the traditional model. Since design and construction are being carried out simultaneously, changes may be more prevalent on a fast track project than with a traditional operation.

When it is successful, fast track construction offers important advantages. It may compress the construction process, saving overall costs and giving the owner a more immediate return on investment by allowing early occupancy. There are, nevertheless, potential risks implicit in the process. Construction may have to commence based upon incomplete documents. This deficiency may create more chance for error because there is no final time for a full-fledged check of the architect's documents before construction is under way. Change orders may become necessary as the project documents are refined. Finally, fast track construction may require an early commitment of construction dollars, before final costs can be determined.

Standard form industry documents, such as those of the American Institute of Architects, were developed around the traditional, sequential system of design, bid, and construct. Fast track documents must be tailored to the project and refined as the work progresses. One early decision is whether to include a costfixed provision, establishing a maximum amount for the overall budget. In the past, such provisions have often required architects to redesign the project if costs began to exceed the budget limit. In a fast track system, where construction is already under way before the design is completed, total redesigning is not possible.

Conflicts, omissions, and errors are common elements of the fast track procedure. Owners may have to approve change orders on short notice. Accordingly, a

8. For example, elevators and certain exterior walls may require up to a one ycar lead time. 
greater investment in changes may be required than under a traditional system. Careful consideration needs to be given to developing an effective means of approving and recording change orders.

\section{B. Design-Build}

The design-build technique consolidates some of the contractual relationships of the parties. The owner hires a single entity to become responsible for both the design and construction of the project. The general contractor is a prime contractor with the architect as a subcontractor, or vice versa. These two entities may enter into a joint venture agreement.

Design-build starts with an agreement between the owner and the designbuilder concerning the overall project and budget parameters. Generally, a lumpsum contract is drafted. Actual performance resembles the traditional model except that the architect's traditional role of the "independent professional" protecting the owner's interests is absent. Accordingly, the owner must have complete faith in the design-builder.

1. Potential Problems Removal of the third party owner representative leaves open several issues: (1) responsibility for periodic inspections of performance; (2) quality control over the work being done; and (3) on-site dispute settlement procedures over such items as approval of change orders, time extension requests, and administration of the payment schedule. Under the traditional model, these items are the responsibility of the architect or engineer who serves as the on-the-job independent referee during the construction phase. Under the design-build model there may be no one filling such a role on behalf of the owner. Thus, there is a need for providing for alternate dispute settlement methods.

2. Effect on Collateral Parties Financial lenders usually rely on the architect or engineer to protect their interests in the project by issuing a certification of completion prior to release of payments. Under a design-build contract, lenders may have to hire their own experts to review the project or may require the owner to provide independent professional review.

Municipal, county, or state agencies which inspect buildings generally rely on the design professional, as an independent source, to ensure that drawings and specifications meet all codes and that the construction complies with the drawings. Periodic reports to that effect may be required. Design-build eliminates the design professional who can render an independent opinion.

Finally, some concern has been expressed that the public's interest is compromised by the design-build model. The architect's license provides some degree of protection of the public interest. When the architect is no longer an independent entity, the interests of the public may suffer.

\section{The Construction Manager}

The construction manager (CM) is a professional consultant to the owner, generally working for a fixed fee unlike a contractor or design-builder who generally 
operates on an entrepreneurial basis. A CM may supervise the design and construction phase and also manage the financing, accounting, and tenant and leasing activities and even become involved in the site selection. In essence, the CM becomes the owner's representative. The position is similar to that of the "master builder" of ancient times whose responsibilities spanned both the design and construction phases of the building process. ${ }^{9}$

A project developed under a construction management model usually focuses on a "team approach," with the CM as the "team leader." It can be employed with the traditional design, bid, and build scheme. More frequently, this model is used in conjunction with fast track performance. One criticism of the fast track approach has been that the design professional lacks sufficient practical experience for complex materials acquisition and scheduling. CMs may bring such expertise when working directly with an architect or engineer.

For complex projects, the CM approach offers certain advantages. It is hardly a panacea and should probably not be used on jobs that do not require a high degree of managerial sophistication. The CM enjoys broad managerial authority without concomitant legal responsibility. Just where a CM's liability begins and an architect's traditional liability ends is a troublesome area. In many jurisdictions, tasks included within licensing requirements for the practice of architecture would overlap the role of CM.

Legislative clarification of the CM's role may become necessary before the process becomes broadly acceptable to design professionals who believe that an architect's liability should be in proportion to control of the construction phase of the project. In theory at least, the CM does not seek to alter or supplant the functions of the design professional. Therefore it can be argued that the architect's professional responsibility is not diminished. The architect remains responsible for onsite observations, ${ }^{10}$ observation reports, ${ }^{11}$ approval of manufacturers, ${ }^{12}$ materials and supplies, ${ }^{13}$ and interpretation of the work drawings. ${ }^{14}$ The routine work carried out by the CM can be viewed as providing an additional resource rather than impinging upon the design professional's traditional function of contract administration.

\section{IV \\ Modern Construction Systems' Impact on Dispute RESOLUTION}

What one can say about all of the above "performance models" is that, although they may save time and reduce overall cost by modernizing and rationalizing the design-construction process, they also may be subject to unknown, contingent liabilities that could impose a higher degree of risk upon the owner and, in

9. Davis \& White, How to Avoid Constnection Headaches, HARv. Bus. REv., Mar.-Apr. 1973, at 87, 89.

10. American Institute of Architects, Standard Form of Agreement Between Owner and Architect,

Doc. B141/CM, art. 1.5.4. (constr. management ed. June 1980).

11. Id.

12. See id. art 1.2.1.

13. Id.

14. Id. art 1.5.9. 
their turn, upon the other entities involved in the project. Fast track procedures eliminate certain precautionary stages in the evolution of the construction process. Design-build eliminates the dispute resolution role of the independent architect. Construction management eliminates certain traditional checkpoints. In a particular job, whether the owner will be better off selecting a "performance model" will of course depend upon a multitude of factors.

There will be a continuing need for rational dispute-settlement mechanisms in the contract documents. If anything, these new "performance models" are likely to increase the number of disputes that may require third party resolution. With the fast track system, the demands placed on the work schedule will be a potential source of disputes. Any delay will necessarily affect the whole project, requiring modification throughout the project scenario. Finding the cause and effect of delay is always a major issue in arbitration. When the construction phases are commingled, the problem will be even more acute. A similar problem is evident with change orders. Fast track documents tend to be unique to the given project, being developed and refined as work progresses. In contrast, standard form documents used in the industry have been tested frequently in both arbitration and in the courts.

Disputes that arise under a design-build model cannot rely upon the first-step settlement procedure available under the traditional model, with the design professional acting as a third party decisionmaker. Thus, unresolved issues must go directly to arbitration or some other dispute resolution method. Documents established by the Assocated General Contractors based on design-build provide for continuation of the work pending settlement by arbitration. The American Institute of Architects has not yet developed a similar accommodation for the designbuild model.

The CM approach does not disrupt the traditional owner-architect, ownercontractor, and contractor-subcontractor relationships. Controversy may arise between the owner and the various design professionals. Architects are calling for statutory definition of the role of CMs, particularly as to scope of liability. An arbitrator, presented with an owner-architect dispute arising out of a project using a CM, may be faced with such an issue.

\section{$\mathrm{V}$ \\ Optional Dispute-Settlement Systems}

Effective dispute settlement under the evolving "performance models" described above may require somewhat more virtuosity than was once required. The issue-by-issue arbitration model may no longer be appropriate. Fortunately, voluntary dispute settlement has great flexibility. It may be helpful to list various optional settlement procedures to fit a variety of situations and contractual models. For purposes of comparison, some of the choices are as follows:

\section{A. Binding Arbitration}

Under binding arbitration, the award will settle all controversies or claims arising under or relating to the contract or the breach thereof, pursuant to the 
terms and provisions of applicable arbitration law. This is the traditional role of arbitration in construction contracts.

When parties wish to use final and binding arbitration, the following clause, or a clause to like effect, can be inserted in the agreement:

Any controversy or claim arising out of or relating to this contract, or the breach thereof, shall be settled by arbitration in accordance with the Construction Industry Arbitration Rules of the American Arbitration Association, and judgment upon the award rendered by the arbitrator(s) may be entered in any court having jurisdiction thereof. ${ }^{15}$

\section{B. Nonbinding Arbitration}

Under nonbinding arbitration, the award of the arbitrator does not legally bind the parties but may be introduced as evidence as a matter of right in any subsequent proceeding.

Where parties wish to use nonbinding arbitration, the following clause, or a clause to like effect, should be inserted in the agreement:

Any controversy or claim arising out of or relating to this contract, or the breach thereof, shall be submitted to nonbinding arbitration in accordance with the Construction Industry Arbitration Rules of the American Arbitration Association. The award of the arbitrator shall not legally bind the parties, but may be introduced as a matter of right in any subsequent proceeding.

\section{Mediation/Arbitration}

This method of resolving disputes involves the designation of an impartial expert, called a mediator/arbitrator, either in the original contract, through mutual agreement of all parties at the beginning of the contractual relation, or by selection by the AAA. As agreed to by the parties or incorporated in the original contract, in the event that a dispute arises, the mediator/arbitrator may:

(a) meet at any time with anyone connected with the matter in dispute, to investigate, inspect, or discover facts relevant to the controversy;

(b) thereafter call together all interested persons or parties for negotiating sessions;

(c) retain engineers, attorneys, and technical experts for the purpose of obtaining independent advice concerning the issues in dispute;

(d) engage in mediation with the parties, either separately or together;

(e) determine that certain issues are appropriate for arbitration, hold hearings concerning such issues, determine such issues and incorporate such determinations in an award that is final and binding on the parties involved.

When parties desire to use a mediator/arbitrator, the following clause can be inserted in the agreement:

Any controversy or claim arising out of or relating to this contract, or the breach thereof, shall be settled by a mediator/arbitrator in accordance with the Construction Industry Arbitration Rules of the American Arbitration Association. The mediator/arbitrator shall endeavor to secure settlement of the controversy or claim by and between the parties themselves, with the aid and advice of the mediator. In the event that the mediator/arbitrator

15. For a more detailed binding arbitration clause, see AIA General Conditions, supra note 1, art. 7.9.1. 
deems it appropriate, or upon demand of any party to such controversy or claim made to the American Arbitration Association, the matter shall be settled by final and binding arbitration conducted by the mediator-arbitrator in accordance with the rules hereinabove referred to, and judgment upon the award rendered by the arbitrator may be entered in any court having jurisdiction thereof.

\section{Mediation}

Mediation is the effort of an individual or individuals to assist the parties in reaching a settlement of a controversy or claim by direct negotiations between or among themselves. A mediator participates in the negotiations and acts as an impartial advisor and consultant to the various parties involved but cannot impose a settlement. The mediator only seeks to guide the parties to direct their own settlement. Where parties wish to use mediation, the following clause, or a clause to like effect, should be inserted in the agreement:

Any controversy or claim arising out of or relating to this contract, or the breach thereof, shall be submitted to mediation in accordance with the Construction Industry Mediation

Rules of the American Arbitration Association.

Mediation is a flexible procedure because the neutral person is free to use a wide variety of strategies. Having no interest in the terms of the ultimate settlement, the mediator simply attempts to guide the parties in reaching their own terms. It remains within the discretion of the parties to withdraw from the mediation at any time. It is agreed by the parties at the outset that nothing that transpires during mediation will affect any of their rights or prejudice their positions in a subsequent arbitration or other proceeding, should such become necessary.

A successful mediation may serve to eliminate the need to prepare for the more formal and adversarial procedures of arbitration or litigation. Even when full accord is not realized, however, a partial settlement can be achieved that will simplify any arbitration proceeding that may follow.

\section{E. Impartial Advisory Committee}

Exceptionally large or complicated projects are likely to encounter unexpected problems during their execution. These problems emerge slowly, with job-level management sometimes failing to appreciate their gravity. By the time their full implications become apparent, both parties may have assumed positions that are difficult to reconcile.

It is fairly common practice for an owner to engage a consultant to review the technical aspects of the work from time to time. Perhaps an independent working group of consultants may be created. Because it is the creation of the owner alone, such a consultant group's advice on contractual problems may not be as well received by the contractor as advice from a board jointly selected by both contracting parties.

On many projects, an impartial advisor or advisory committee representing various disciplines could not only provide technical assistance but could promote cooperation between the parties in the solution of contractual problems before they become unmanageable. By anticipating problems and proposing solutions 
before the problems become serious, such a committee could, in the long run, prove less expensive than other methods of dispute adjudication.

The AAA will, if desired, recommend and appoint impartial advisors as desired by the parties and assist in the administration of the advisory program. When the parties wish to incorporate provisions for an impartial advisor or advisors in their agreement, the following clause, or a clause to like effect, should be inserted therein:

Any potential controversies or claims arising under or relating to the terms and conditions of this contract, or the breach thereof, shall, upon written request of either party, be submitted to an impartial advisor (or impartial advisory committee). The advice of such advisor (or committee) shall be nonbinding on the parties involved.

One or more of these optional systems can be adopted by the parties to fit their particular project. Under the "performance model," it may make sense to designate an acceptable arbitrator or mediator/arbitrator well in advance so that disputes can be resolved rapidly as they arise. In some situations, the designated neutral should be briefed as to the project in advance so that, in addition to general expertise, the impartial person will bring specific knowledge of the construction contract to the first hearing.

If arbitration is selected as the appropriate mechanism, certain amendments may be made in the usual procedure. Hearings should be available on demand. The arbitrator might be appointed for the term of the contract. Expedited procedures of various kinds can be arranged.

\section{VI}

\section{CONCLUSION}

The "performance model" construction techniques will present new challenges, not only to builders but also to dispute resolution institutions. These new techniques will increase, in varying degrees, the likelihood that controversies will develop. A flexible strategy will be required in response; traditional arbitration will not always be appropriate. Under the design-build format, when the role of the architect as the first-level decision-maker for dispute settlement is eliminated, construction mediation may fill the void.

Since the aim of fast track construction is speed and economy, construction arbitration will continue to provide an attractive alternative to litigation. On-site arbitration and mediation can be very effective; but, as is always the case when dealing with voluntary dispute settlement mechanisms, these systems will only work if qualified, experienced arbitrators and mediators are in control. The parties' attorneys also play a crucial role in making these processes work effectively. Arbitration has the capacity for providing prompt and economical justice; its success depends upon all involved in the process. 
